\title{
Ahistorisitas Penafsiran dan Bias Ideologi (Kajian Terhadap Konsep Kedaulatan Tuhan Menurut Sayyid Quṭb)
}

\begin{abstract}
Ahlam Irfani ${ }^{1}$
Abstract

The ideological bias in Qur'änic interpretation cannot be fully eliminated. Its existence, however, can be reduced. The historical interpretation -- considered by some - can respond to this ideological challenge.

To prove this statement, this writer will describe Sayyid Qutb's interpretation in his political concept, especially hākimiyyah or God's sovereignity in his Fì Zilāl al-Qur'ān. The ta'wīl of $A b \bar{u}$ Zayd, enriched by the critical discourse analyses and social cognition of van Dijk, will be used to prove that the more ahistorical an interpretation the more ideological it is.
\end{abstract}

\begin{abstract}
Abstrak
Bias ideologi dalam ranah eksegesis memang tidak bisa dihilangkan. Namun, eksistensinya dapat direduksi. Penafsiran yang historis, dinilai mampu untuk menjawab tantangan praktik ideologi ini.

Maka untuk membuktikan hal tersebut, penulis akan memotret penafsiran Sayyid Qutb terhadap konsep politiknya, yaitu hākimiyyah atau konsep kedaulatan Tuhan dalam tafsir Fi Zilāl al-Qur'ān. Metode ta'wīl Abu Zayd, yang diperkaya dengan analisis wacana kritis dan pendekatan kognisi sosial van Dijk, akan penulis gunakan untuk membuktikan bahwa semakin ahistoris sebuah penafsiran, semakin ideologis.
\end{abstract}

Keywords: penafsiran historis, ahistoris, hạkimiyyah (konsep kedaulatan Tuhan), dan radikal. ahlam.irfani@gmail.com

1 Kepala Sekolah Madrasah Ibtidaiyah al-Itroh, Jakarta Selatan. E-mail: 


\section{Pendahuluan}

Histori ataupun sejarah, menurut ibn Khaldun-sebagaimana dikutip oleh Noeroezzaman Shiddiqi-bukanlah sekedar cerita masa lalu, melainkan upaya melibatkan spekulasi dan upaya untuk menemukan kebenaran, eksplanasi kritis tentang sebab dan genesis kebenaran sesuatu dan kedalaman pengetahuan tentang "bagaimana" dan "mengapa" mengenai peristiwa-peristiwa. Dengan kata lain, tugas sejarawan adalah "menyeleksi fakta dan meneliti penyebabpenyebabnya." Maka, pengetahuan sejarah tidak hanya menyeleksi fakta-fakta apakah ia asli atau bukan? tetapi juga meneliti penyebab-penyebab terjadinya suatu peristiwa. Apabila poin kedua ini dikaitkan pada al-Qur'ān, maka yang diperlukan adalah penyebab turunnya al-Qur'ān (asbāb nuzū $)$, sebagai jalan untuk memahami dan menafsirkan ayat-ayat al-Qur'ān. Jadi, yang dimaksud dengan historisitas al-Qur'ān di sini, tidak menyentuh ranah keaslian dari kisahkisah atau ayat tersebut, melainkan menyentuh aspek pemaknaannya, yang ditunjukkan dengan aspek historis ayat atau sebab turunnya ayat tersebut. ${ }^{2}$ Historisitas yang menyentuh level pemaknaan atau interpretasi tersebut, telah lebih dahulu diadopsi oleh penafsir modernis semisal Abū Zayd (ahli bahasa, heremeneut asal Mesir, 1943 M-2010 M), Hassan Hanafí (1. 1935 M- ), Fazlur Rahman (pemikir Islam asal Pakistan, 1919 M-1988 M) dan Khaled Abou elFadl (1. 1963). Apa yang mereka lakukan ini, bukan berarti mengabaikian otentisitas al-Qur'ān, karena penafsir-penafsir tersebut menganggap bahwa permasalahan mengenai otentisitas al-Qur'ān telah selesai atau terbukti. Hal ini memang berbeda dengan pendapat sebagian orientalis, yang justru menyimpulkan bahwa al-Qur'ān adalah buatan Muhammad, dengan menggunakan kritik historis sebagai pisau analisisnya. ${ }^{3}$

2 Nourouzzaman Shiddiqi, "Sejarah: Pisau Bedah Ilmu Keislaman," dalam Metodologi Penelitian Agama: Sebuah Pengantar, ed. Taufik Abdullah dan M. Rusli Karim (Yogyakarta: Tiara Wacana Yogya, 1990), 69-70.

3 Hassan Ḥanafi misalnya, sebagaimana yang diteliti oleh Ilham B. Saenong, bahwa Hanafi menggunakan kritik historis dalam hermeneutika pembebasannya. Namun, kritik historis tersebut justru mengantarkannya kepada kesimpulan bahwa al-Qur'an adalah asli dari Allah dan bukan buatan Muhammad. Hanafí beralasan bahwa keaslian alQur'an dalam sejarah ditemukan ketika tidak ada syarat-syarat kemanusiaan di dalamnya. Dan dalam kasus al-Qur'an, kata-kata yang diterima Muhammad adalah langsung oleh Tuhan melalui malaikat, kemudian langsung didiktekan oleh Muhammad kepada para penyalinnya pada saat pengucapan, dan lestari sampai saat ini dalam tulisan. Syarat lain menurut Ḥanafí adalah keutuhannya. Artinya, wahyu tersebut tidak mengalami penambahan atau pengurangan dalam sejarah. Begitu juga dengan Fazlur Rahman, ia mengatakan bahwa kesimpulan yang menyatakan bahwa al-Qur'an adalah buatan Muhammad adalah tidak adil. Karena apa yang dilakukan orientalis tersebut, 
Berdasarkan uraian ini, penulis menegaskan bahwa yang dimaksud dengan ahistorisitas penafsiran adalah penafsiran yang tidak terdapat kesinambungan antara konteks sabab nuzūl atau makna dasar ayat dengan kontekstualisainya. Oleh karena itu, penulis menggunakan teori epistemologi dan ideologi Abū Zayd, yang menafsirkan al-Qur'ān berdarkan historisitasnya, yakni sebab turunnya al-Qur'ān atau makna dasar ayat jika ayat tersebut tidak memiliki sabab nuzūl, yang kemudian ia kembangkan menjadi teori ma'nā dan maghzä. .

Lebih lanjut mengenai aspek historis dalam ranah eksegesis, selain digunakan untuk menemukan makna dari suatu teks, juga dinilai mampu mereduksi subyektivitas penafsir, ${ }^{5}$ bahkan sebagian kalangan menilai bahwa penafsiran ideologis-tendensius, dari yang pasif sampai radikal, adalah akibat

menurut Rahman lebih disebabkan oleh faktor “outsider." Kendati demikian, Rahman tidak menggeneralisir hal tersebut pada semua non-Muslim yang meneliti Islam, karena baginya, syarat tambahan untuk diterimanya penelitian mereka adalah pemahaman yang tidak berprasangka, tidak sensitif dan berpengetahuan banyak. Selain itu, diperlukan pula verifikasi penafsiran mengenai Islam oleh Muslim sebagai syarat tambahan. Lihat Ilham B. Saenong, Hermeneutika Pembebasan (Bandung: Teraju, 2002), 115-116 dan Fazlur Rahman, "Pendekatan Terhadap Islam dalam Studi Agama," dalam Pendekatan Kajian Islam dalam Studi Islam, ed. Richard C. Martin, penerjemah Zakiyuddin Baidhawi (Surakarta: Muhammadiyah University Press, 2002), 258-259.

${ }^{4}$ Lihat Moch. Nur Ikhwan, Meretas Kesarjanaan Kritis al-Qur'an (Jakarta: Teraju, 2003), 79-80. Memang, tidak semua ayat-ayat al-Qur'an memiliki sabab nuzūl. Dan ayat-ayat yang tidak memiliki sabab nuzūl lebih banyak daripada ayat-ayat yang memiliki sabab nuzūl. Oleh karena itu, dalam penelitian yang mengkhususkan pada konsep kedaulatan Tuhan ini, apabila ada penafsiran Quṭb mengenai konsep tersebut yang tidak memiliki sabab nuzūl maka peneliti akan menggunakan sha'nu al-nuzūl, yakni apa yang diceritakan ayat itu sendiri, yang juga akan didukung dengan ilmu-ilmu 'ulüm al-Qur'an lainnya seperti 'ilmu al-munāsabāt dan lain-lain, guna mendapatkan makna yang kurang lebih obyektif. Kendati demikian, penafsiran-penafsiran terhadap ayat-ayat yang tidak memiliki sabab nuzūl tersebut dapat disebut "penafsiran ahistoris" dalam penelitian ini, karena peneliti menggunakan teori epistemologi abū Zayd, yang mengartikan bahwa penafsiran ahistoris adalah kata lain adalah penafsiran yang tidak terdapat kesinambungan antara historisitas teks dan obyektifitasnya, dengan signifikansi ayat saat proses kontekstualisasi. Bandingkan dengan, Șubḥi Șālih , Muḥammad Abū Shahbah, al-Madkhal lidirāsat al-Qur'ān al-Karim (kairo: Maktabat al-Sunnah, 2002), 144, Qașabì Mahmūd Zalaṭ, Mabāhith fí 'Ulūm al-Qur'ān (Dubai: Dār al-Qalam, 1987), 55 dan Nasr Hạamid Abū Zayd, Naqd al-Khițāb al-Dīni (Maroko: al-Dar al-Bayda', 2007), 120 .

${ }^{5}$ Sejatinya, memang tidak ada satu pembacaan pun yang bisa terlepas dari ideologi penulisnya. Hal ini bukanlah sesuatu yang negatif, sepanjang sudut pandang penulis tidak mendistorsi objek dan tetap menjadikan teks itu terbuka bagi visi orang lain yang memandangnya. Abdul Mustaqim, Epistemologi Tafsir Kontemporer, 140. 
dari pengabaian aspek historisitas al-Qur'ān. ${ }^{6}$ Namun, sebagian lain justru memilih untuk menjadikan teks bersifat otonom, sehingga berdampak kepada pemberian hak prerogatif kepada pembaca dalam menafsirkannya juga tersingkirnya aspek sejarah pada teks. Berdasarkan hal ini, penulis menyimpulkan bahwa terdapat dua golongan dalam memandang historisitas penafsiran dan pengaruhnya dalam ideologisasi. Kelompok pertama, melihat bahwa semakin ahistoris sebuah penafsiran, semakin ideologis. ${ }^{7}$ Sedangkan kelompok kedua, berpendapat bahwa semakin ahistoris sebuah penafsiran, semakin membumi. ${ }^{8}$

Adapun yang termasuk dalam kelompok pertama di antaranya adalah Khaled Abou el-Fadl. ${ }^{9}$ Dalam penjelasannya tentang teks dan otoritas, ia menyatakan bahwa pembacaan ideologis yang berujung kepada otoritarianisme $^{10}$ bahkan radikalisme dalam interpretasi al-Qur'ān maupun Hadis, kebanyakan terjadi karena pendekatan yang digunakan bersifat ahistoris. Jadi, teks dipaksa untuk tunduk kepada ideologi penafsir dengan mengabaikan

${ }^{6}$ Budhy Munawwar-Rachman dan Mohammad Shofan, Argumen Islam untuk Liberalisme (Jakarta: Grasindo, 2010 )169.

${ }^{7}$ Pengertian ideologi dalam tulisan ini, merujuk kepada definisi Abū Zayd. Menurutnya, ideologi adalah bias interpreter. Ia adalah orientasinya, keyakinan yang kemudian membimbing, sementara seharusnya ia memeranginya. Dengan kata lain, ideologi adalah keyakinan yang belum terbukti secara akademik dan ilmiah, berbeda dengan epistemologi, yang menyentuh level kesepakatan bersama. Lihat Moch. Nur Ikhwan, Meretas Kesarjanaan Kritis al-Qur'an, 87.

${ }^{8}$ Maksud dari ungkapan pertama, semakin sebuah penafsiran tidak melihat kepada aspek sosio-historis dalam sebuah kontektusalisasi makna, semakin teks itu mudah dikuasai oleh ideologi penafsirnya. Sedangkan yang kedua, semakin sebuah penafsiran itu tidak melihat kepada aspek sosio-historis, semakin ia membumi atau dekat dengan realita. Kedua teori ini berkaitan erat dengan pembagian metodologi penafsir kontemporer oleh Ilham B. Saenong. Lihat Ilham B. Saenong, Hermeneutika Pembebasan, Metodologi Tafsir al-Qur'an, 94.

${ }^{9}$ Seorang guru besar bidang hukum Islam di universitas UCLA Los Angeles yang lahir di Kuwait tahun 1963. Ia banyak dianugerahi berbagai penghargaan, diantaranya penghargaan atas pembelaannya terhadap HAM. Ia juga ditunjuk sebagai sebuah dewan komisi di Amerika yang khusus mengurusi kebebasan beragama. Ia juga banyak menulis buku-buku yang berkenaan tentang Islamic studies. Lihat "Khaled Abou el-Fadl" dalam UCLA School of Law, 2011, http://www.law.ucla.edu/faculty/all-facultyprofiles/professors/Pages/khaled-abou-el-fadl.aspx (diakses pada 14 Oktober 2012) .

${ }^{10}$ Otoritarianisme yang dimaksud oleh Abou el-Fadl adalah tindakan dari orangorang yang menggunakan simbolisme dari komunitas interpretasi hukum tertentu untuk mendukung argumen mereka. Singkatnya, mereka menggunakan seperangkat bentukbentuk simbolis yang mengebiri otoritas budaya hukum demi melayani kepentingan si pelaku. Lihat Khaled Abou el-Faḍl, Atas Nama Tuhan, penerjemah R. Cecep Lukman Yasin (Jakarta: Serambi Ilmu Semesta, 2001), 160. 
aspek historis teks tersebut, sehingga dampak yang ditimbulkan adalah bias penafsir yang menggantikan teks. ${ }^{11}$

Adapun kelompok kedua, ${ }^{12}$ di antaranya adalah Muhammad Shahrur.. ${ }^{13}$ Dalam menafsirkan al-Qur'ān ia menggunakan pendekatan linguistik strukturalis, yang berujung kepada sikap otonomi teks. Salah satu implikasi dari pendekatan ini, adalah penolakan atas digunakannya asbāb nuzūl. Kalaupun ia menggunakannya, hanya untuk mendukung teori yang cocok dengan pemikirannya, seperti yang terlihat pada metode hudud ${ }^{14}$ dan ta'wil ${ }^{15}$ yang digunakan. ${ }^{16}$

11 Khaled Abou el-Fadl, Atas Nama Tuhan, penerjemah R. Cecep Lukman Yasmin, 154. Selain Abou el-Fadl ada juga Nașr Hāamid Abū Zayd. Ia memperkenalkan sebuah metode dalam pembacaan al-Qur'an, yaitu metode ta'wil atau qirā'ah muntijah sebagai lawan dari qirā'ah mughriḍah (pembacaan ideologis-tendensius). Singkatnya, sebuah penafsiran bisa dikategorikan sebagai qirā'ah muntijah jika terdapat kesinambungan antara ma'nā dari suatu ayat (dan ma'nā tersebut, bisa diketahui setelah menelaah aspek historis yang berkenaan dengan ayat yang bersangkutan) dengan signifikansinya (yang dapat diketahui dari ma'na itu sendiri). Dan untuk selanjutnya, signifikansi ini digunakan sebagai parameter dalam mengaktualisasikan ayat tersebut. Jadi, ta'wīl miliknya ini, mengharuskan adanya kesinambungan antara ma'nā dan maghzā. Karena jika tidak, interpretasi tersebut menjadi interpretasi ideologistendensius (talwīn). Nasr Hāmid Abū Zayd, Naqd al-Khițāb al-Dīnī (Maroko: al-Dar alBayda', 2007), 231 dan Moch. Nur Ikhwan, Meretas Kesarjanaan Kritis al-Qur'an (Jakarta: Teraju, 2003), 84-85

${ }^{12}$ Kelompok kedua ini, sering beranggapan bahwa menggunakan sabab nuzūl tidak relevan untuk masa kini, khususnya dengan kaidah al-'ibrah bi 'umūm lafž. Hal ini sebenarnya dibantah dengan kaidah itu sendiri. Pasalnya, baik kaidah yang menyatakan bahwa pegangan dalam menafsirkan itu keumuman lafaz atau kekhususan sebabnya sama-sama menghasilkan out put yang sama dan sama-sama sepakat akan keumuman hukum. Yang membedakan hanya cara dalam menghasilkan pendapat tersebut. Apabila kaidah al-'ibrah bi 'umüm lafz, maka cara yang diapakai adalah dengan menjadikan ayat yang besangkutan sebagai dalil. Adapun kaidah al-'ibrah bi khuṣuṣ al-sabab, dengan menjadikan metode qiyās atau analogi. Bandingkan dengan Muhammad Abū Shahbah, al-Madkhal li Dirāsat al-Qur'ān al-Karīm, 146 dan .Qaṣabì Mạ̣mūd Zalāt, 'Ulūm alQur'ān (Dubai: Dār al-Qalam, 1987), 52.

${ }^{13}$ Lulusan teknik sipil ini, lahir di Suriah pada 11 April 1938. Ia mendapatkan gelar diploma di bidang Teknik Sipil di Moskow, Uni Soviet (sekarang Rusia). Sedangkan program megister dan doktoral ia selesaikan di Irlandia. Ketika di Moskow inilah ia mulai terkesan dan terpengaruh dengan pemikiran Marxian, juga dengan tradisi Formalisme Rusia, yang mana akar-akarnya diadopsi dari strukturalisme linguistik yang digagas oleh de Saussure. Oleh karena itu, dalam menafsirkan al-Qur'an, nuansa linguistiknya amat kental. Bandingkan dengan Ahmad Zaki Mubarak, Pendekatan Strukturalisme Linguistik dalam Tafsir al-Qur'an Kontemporer "ala” M. Shahrür (Jogjakarta: ELSAQ Press, 2007),136.

${ }^{14}$ Adalah metode khusus yang digunakan dalam kitāb al-risālah, yakni, bagian dari al-Qur'an yang hanya memuat ayat-ayat muhkamāt, atau ayat-ayat hukum. Dan 
Melihat alasan dari masing-masing kelompok, dapat disimpulkan bahwa kelompok kedua memandang bahwa penafsiran yang ahistoris, membuat teks semakin membumi, sedangkan kelompok pertama cenderung menolaknya, karena hal tersebut bisa berdampak kepada melebarnya bias kepentingan penafsir di dalamnya. ${ }^{17}$ Dari perdebatan ini, penulis sependapat dengan kelompok pertama. Adapun untuk membuktikan hal tersebut, penulis akan memotret penafsiran Sayyid Quṭb terhadap hăkimiyyah (konsep kedaulatan Tuhan).

\section{Definisi Hākimiyyah}

Sebelum melangkah lebih jauh, penulis akan membahas hākimiyyah dari segi etimologi. Hākimiyyah adalah mashdar sinā' $\bar{i}$ dari kata $h-k-m$. Oleh karena itu, untuk mengetahui lebih lanjut mengenai arti dari hākimiyyah, perlu diketahui arti kata dari $h-k-m$ itu sendiri. $H-k-m$ dalam beberapa kamus seperti

teori hudùd ini dibagi menjadi dua, fỉ al- 'ibàdah dan fì al-aḥkām. Lihat Abdul Mustaqim, Epistemologi Tafsir Kontemporer, 215.

${ }^{15}$ Metode ta'wìl yang ia gunakan khusus dalam kitäb al-Qur'ān-teminologi khusus yang berarti ayat-ayat mutashābihāt - menggunakan pendekatan linguistik dan teori sains modern. Dan tolok ukur dalam metode ini adalah realita.

${ }^{16}$ Abdul Mustaqim, Epistemologi Tafsir Kontemporer, 190. Selain Shahrūr, ada pula Ḥasan Ḥanafi yang terkenal dengan hermeneutika pembebasan. Lebih lanjut mengenai hermenutika Hanafi, ia mengatakan bahwa hermenutikanya bersifat "teoritik" dan "praktis". Oleh karena itu, dalam hemeneutika pembebasan ini, pembaca akan menemukan tiga fase untuk mewujudkan tujuannya tersebut. Pertama, kritik historis yang berguna untuk menemukan otentisitas sebuah teks. Karena baginya, sebuah interpretasi dapat dilakukan setelah mengetahui keotentikan suatu teks. Kedua adalah analisis makna. Menurutnya, dalam memulai penafsiran seorang penafsir harus memulai pekerjaannya dengan tabula rasa, yakni tidak boleh ada kecuali analisis linguistiknya. Dan ketiga adalah kritik praksis. Jadi, pemahaman yang berangkat dari realitas masa kini menuju pemahaman yang sesuai dengan ajaran-ajaran yang mungkin diperoleh dari penafsiran al-Qur'an. Oleh karena itu, sebuah dogma menurutnya, hanya dapat diakui eksistensinya jika dapat terealisasi dalam tindakan manusia. Lihat Ilham B. Saenong, Hermenutika Pembebasan, Metodologi Tafsir al-Qur'an menurut Hasan Hanafi (Jakarta: Teraju, 2002), 114.

${ }^{17}$ Nampaknya pendapat Komaruddin Hidayat dalam hubungan antara penafsiran sebuah teks dengan aspek psikologis dan historis pengarang, perlu untuk dipaparkan. Menurutnya, terdapat dua kelompok di dalam permasalahan ini. Pertama adalah mazhab hermeneutika transendental. Yaitu yang beranggapan bahwa untuk menemukan kebenaran dalam teks tidak harus mengaitkannya dengan sang pengarang, karena sebuah kebenaran bisa berdiri otonom ketika tampil dalam teks. Kedua, adalah mazhab historispsikologis. Yaitu yang berpandangan bahwa teks adalah eksposisi eksternal dan temporer saja dari pengarangnya, sementara kebenaran tidak mungkin terwadahi secara representatif oleh kerhadiran teks. Lihat Komaruddin Hidayat, Memahami Bahasa Agama, Sebuah Kajian Hermeneutika (Bandung: Mizan, 2011), 214 
Lisān al-'Arab, memiliki banyak arti, pertama adalah al-iṣlāh atau mencegah demi memperbaiki sesuatu. Kedua, $h-k-m$ juga berarti al- 'ilmu wa al-fiqhu yang artinya mengetahui atau memahami. Ketiga, $h-k-m$ berarti mengadili atau memut uskan sesuatu, oleh karenanya, seorang hakim dalam bahasa Arab disebut hākim atau qāọi. Keempat, $h-k-m$ berarti menetapkan. ${ }^{18}$

Adapun hăkimiyyah secara terminologi, sebagaimana yang telah penulis katakan, bahwa dalam penulisan ini penulis akan merujuk kepada definisi hăkimiyyah Hishām Ja'far. Menurut Ja'far, konsep ḥākimiyyah dibagi menjadi dua, hākimiyyah takwiniyyah dan häkimiyyah tashrïiyyah. Adapun yang pertama, berhubungan dengan kebijakan Allah kepada alam semesta, yakni yang tidak berhubungan dengan keinginan manusia, sedangkan yang kedua berhubungan dengan keinginan manusia, yang secara garis besarnya meliputi masalah akidah, ibadah, al-taḩil wa al-tahrim, dan akhlak. Kedua makna hăkimiyyah ini disetujui banyak peneliti. Hanya saja, ada makna lainnya dalam konsep hăkimiyyah ini yang menjadi perdebatan, yakni makna siyāsiyyah. Implikasi dari hal ini, terlihat bagi mereka yang hanya melihat hăkimiyyah dari makna pemerintahannya saja dan menolak makna lainnya. Oleh karena itu, seyogyanya dibutuhkan pengetahuan yang cukup dalam membedakan mana konsep hākimiyyah bermakna diniyyah-takwïniyyah, tashrí'iyyah atau siyāsiyyah. ${ }^{19}$

Konsep kedaulatan Tuhan ini, juga memiliki dua aspek. Aspek akidah dan aspek imtithāti atau pelaksanaan. Perbedaannya, jika dalam aspek akidah, maka penolakan terhadap konsep kedaluatan Tuhan akan berkibat pada kekafiran atau keluar dari Islam. Namun jika penolakan tersebut masih dalam tatanan aspek pelaksanaannya, bukan pada tatanan akidah, maka hal tersebut tidak serta merta membawa seorang muslim kepada predikat kafir. Karena perlu dilihat lebih dahulu, apa alasan penolakan tersebut. Jika alasannya menyinggung masalah akidah, maka hal tersebut membawa kepada kekafiran, namun jika tidak, maka muslim tersebut hanya menjadi fasik atau zalim. ${ }^{20}$

Berdasarkan hal tersebut, penulis menyimpulkan bahwa jika penjelasan atas ayat-ayat yang tidak sesuai dengan konteksnya, berarti bersifat ahistoris atau ideologis. Misalnya, saat menafsirkan ayat-ayat berkonteks tauhid, konsep hăkimiyyah berarti memliki aspek akidah atau tashrí'iyyah. Namun jika

\footnotetext{
${ }^{18}$ Ibn Manzūur, Lisān al- 'Arab vol. 12 (Beirut: Dār al-Ṣadr, tth), 140.

19 Hishām Ahmad Ja'far, al-'Ab'ād al-Siyāsiyah li Mafhūm al-Hākimiyyah (Virginia: al-Ma'had al-'Ālamī li al-Fikri al-Islāmī, 1995), 85

${ }^{20}$ Hishām Aḥmad Ja'far, al- 'Ab ‘àd al-Siyāsiyah li Mafhūm al-Hākimiyyah, 107.
} 
diartikan dengan aspek siyāsī, maka penafsiran tersebut sudah disebut dengan penafsiran ahistoris. $^{21}$

Kendati demikian, jika melihat makna dan aspek yang dimiliki konsep kedaulatan Tuhan dari kaca mata ilmu teologi, sebenarnya konsep ini kembali kepada salah satu sifat Allah yaitu al-qudrah. Mengutip penjelasan al-Būtí, bahwa beberapa sifat-sifat Allah memiliki kesamaan nama dengan sifat yang dimiliki manusia, dan di antaranya adalah sifat qudrah ini. Akan tetapi, yang membedakan antara kedua sifat tersebut ada dua hal: pertama sifat yang dimiliki Allah meskipun memiliki kesamaan nama tapi sifat yang dimiliki-Nya adalah sifat yang haqiq $\bar{i}$, adapun yanag dimiliki manusia hanyalah kekuatan yang tidak seberapa, yang telah diberikan Allah kepada hambanya. Kedua, kesamaan dalam sifat-sifat tersebut hanya dari segi penamaan saja. Pasalnya, jika dibandingkan antara sifat yang dimiliki Allah dengan sifat yang dimiliki manusia, akan terlihat jelas bahwa sifat manusia tersebut tidaklah seberapa jika dibandingkan dengan sifat yang dimiliki Allah. ${ }^{22}$ Terlepas dari hal ini, tulisan ini melihat konsep kedaulatan Tuhan Quṭb dari segi penafsiran, dan bukan dari sisi teologi. Oleh karena itu, dalam penulisan ini, konsep kedaulatan Tuhan tersebut dilihat apakah ia ahistoris (ideologis) atau tidak. Berikut ini, penulis akan menjelaskan penafsiran Quṭ terhadap konsep hăkimiyyah dalam tafsir $F \bar{i}$ Zilāl al-Qur'ān. Berdasarkan penelitian penulis, terdapat tujuh belas ayat yang menjelaskan makna konsep kedaulatan Tuhan, namun tidak semuanya bersifat ideologis. Sependek penelitian penulis, terdapat dua penafsiran yang tidak ideologis, sedangkan sisanya adalah ideologis. Akan tetapi pada tulisan ini, penulis hanya akan menjelaskan sebagian dari contoh-contoh tersebut.

\section{Konsep Kedaulatan Tuhan dalam Tafsir Fỉ zilāl al-Qur'ān}

Ayat pertama yang menjelaskan konsep tersebut adalah Q.S. al-Baqarah (2): 253. Ayat ini mewakilkan penafsiran Qutb yang tidak ideologis. Lebih lanjut, penafsiran Quṭb terhadap Q.S. al-Baqarah (2): 253 menggambarkan bahwa implikasi dari keesaan Allah adalah totalitas manusia dalam menyembah-Nya juga dalam pelaksanaan segala perintah dan menjauhi larangan-Nya. Dari konsep keesaan Tuhan ini lah, muncul sebuah konsep yang dinamakan hăkimiyatullāh (kedaulatan Tuhan), yang dalam penafsiran Quṭb

${ }^{21}$ Contonya akan dijelaskan ada pada ayat yang akan dijelaskan setelah ini. Ayat tersebut (Q.S. al-Baqarah (2): 253), bertemakan tauhid, namun dalam penafsirannya, Quṭb menjelaskan konsep ḥākimiyyah bertemakan qaụai.

22 Bandingkan dengan Muhammad Sa'ỉd Ramaḍān al-Būṭī, Kubrāa al-Yaqīniyāt (Damaskus: Dār al-Fikr, 1982), 117-118. 
adalah, hanya Allah lah yang berhak membuat syariat. Oleh karenanya segala macam peraturan dalam kehidupan manusia sudah sepantasnya berkiblat kepada syariat Allah. ${ }^{23}$

Apa yang dikatakan oleh Quṭb tersebut, jika kembali kepada penelitian Hishām Ja'far, menunjukkan kepada konsep kedaulatan Tuhan bermakna tashri'iyyah. ${ }^{24}$ Selain itu, meskipun Quṭ membicarakan konsep kedaulatan Tuhan beraspek imtithăli dalam ayat akidah, hanya saja penjelasannya itu hanya sebatas makna dasar dari konsep kedaulatan Tuhan. ${ }^{25}$ Oleh karena itu, penafsiran Quṭb tidak ahistoris terlebih lagi radikal.

Lebih lanjut mengenai penafsiran Quṭb tersebut, nampaknya ia memang berkonsentrasi pada makna konsep kedaulatan Tuhan. Pasalnya, jika dibandingkan dengan penafsir-penafsir lainnya, mayoritas dari penafsir-penafsir tersebut menjelaskan lebih dahulu riwayat-riwayat yang berkenaan dengan keutamaan ayat. Sebut saja ibn Kathïr (seorang mufassir sunni,700 H-774 H). Dalam menjelaskan ayat tersebut, ibn Kathïr menyebutkan beberapa riwayat mengenai keutamaan ayat tersebut. Setelah itu, ia pun menjelaskan makna literal dari tiap kata serta hikmah yang terkandung di dalamnya. ${ }^{26}$ Hal senada juga dilakukan oleh penafsir lainnya seperti al-Alūsi (1802 M-1854 M), abū Hayyān (654 H-754 H) dan al-Rāzì (1149 M-1209 M). Para penafsir itu juga tidak menjelaskan mengenai konsep kedaulatan Tuhan seperti yang dilakukan Qutb. ${ }^{27}$

Adapun dari segi tema, penafsiran Quṭb tersebut menggambarkan bahwa tema yang diusungnya kali ini adalah sifat-sifat Allah serta hubungannya dengan konsep kedaulatan Tuhan. Hal ini terbukti dengan penjelasan Qutb sebelum ia menjelaskan ayat secara terperinci. Struktur penafsiran juga menunjukkan hal yang sama, pasalnya Quṭb langsung menjelaskan "makna dalam" ayat, yang tidak lain adalah konsep kedaulatan Tuhan, pada awal penafsirannya dan bukan "makna luar" darinya. Hal ini setidaknya

${ }^{23}$ Sayyid Quṭb, Fì Zilāl al-Qur’ān vol.1 (Kairo: Dār al-Shurūq, 2003), 286.

${ }^{24}$ Hishām Aḥmad Ja'far, al-'Ab'ād al-Siyāsiyah li Mafhūm al-Hākimiyyah, 90.

${ }^{25}$ Makna dasar konsep kedaulatan Tuhan adalah, kedaulatan mutlak hanya milik Allah, oleh karena itu, hanya ia yang berhak membuat syariat dan segala peraturan sudah sepantasnya berjalan sesuai dengan syariat-Nya. Bandingkan dengan Hishām Ạ̣mad Ja'far, al-'Ab'àd al-Siyāsiyah li Mafhūm al-Hākimiyyah, 72.

${ }^{26}$ Ibn Kathīr, Tafsìr al-Qur'ān al- 'Azìim (Kairo: Dār al-Āthār, 2009), vol. 1, 687.

${ }^{27}$ Bandingkan dengan al-Âlūsì, Rüh al-Ma ānì (Beirut: Dār Ihyā' al-Turāth al'arabī, 1981),vol. 2, 311, Abū Hayyān, al-Bahru al-Muhịt (Beirut: Dār al-Kutub al'ilmiyyah, 1993), vol. 3, 10 dan Fakhru al-Din al-Rāzì, Mafätịh al-Ghayb (Beirut: Dār alFikr, 1980), vol. 3, 441. 
membuktikan, bahwa Quṭb membangun konsep kedaulatan Tuhan miliknya di atas konsep tauhid. ${ }^{28}$

Kesimpulan di atas didukung oleh penjelasan yang diberikan Quṭb. Pasalnya, dalam menjelaskan kalimat al-tauhid dalam ayat Q.S. al-Baqarah (2): 255, penafsirannya tersebut dihabiskan hanya untuk menjelaskan hubungan antara akidah dengan konsep kedaulatan Tuhan. Hal ini lah yang kemudian menjadi salah satu sebab kerancuan dalam memahami konsep kedaulatan Tuhan, karena Qutb dinilai telah mencampuradukkan antara makna konsep kedaulatan Tuhan bermakna akidah dengan makna syar'iyyah. Implikasi yang terjadi adalah pengkafiran pada semua muslim yang tidak menjalani syariat Islam secara komprehensif. ${ }^{29}$ Meskipun demikian, Quṭ hanya menjelaskan konsep kedaulatan Tuhan, dalam ayat ini, hanya pada kalimat al-tauhid tidak pada keseluruhan ayat Q.S. al-Baqarah (2): 255. Oleh karenanya, menurut penulis, penafsiran Quṭb tersebut tidak ahistoris, karena konsep kedaulatan Tuhan yang dibahas masih dalam kewajaran dan sesuai dengan konteks. ${ }^{30}$

Contoh penafsiran Qutb yang tidak ideologis lainnya adalah penafsiran 'Āli 'Imrān (3): 32. Ayat tersebut menceritakan perintah Allah bagi umat-Nya untuk menaati Allah, Rasul dan kitabnya. Selain itu, di dalam ayat tersebut terdapat celaan terhadap mereka yang mengaku beriman, namun tidak mau mengikuti apa yang diperintahkan Allah dan Rasul-Nya. ${ }^{31}$

Membicarakan konteks ayat Âli 'Imrān (3): 32, ibn Jarir mengatakan bahwa ayat tersebut turun dalam kontek utusan kaum Nasrani dari Najrān, yang dikenal dengan sebutan Nașārā Najrān, kepada Nabi Muhammad. Singkatnya, dalam kitab Injil telah termaktub bahwa akan ada nabi akhir zaman dengan ciri-

${ }^{28}$ Bandingkan dengan John Calvert, Sayyid Qutb and the Origin of Radicalism (London: C. Hurst and Co, 2010), 202 dan Thameem Ushama, "Extremism in the Discourse of Sayyid Qutb: Myth and Reality," Intelectual Discourse (2007): 167-168, http://www.iium.edu.my/intdiscourse/index.php/islam/article/view/49 (diakses pada 18 Januari 2014).

${ }^{29}$ Di antaranya adalah al-Qaraḍāwi, Tạāā Jābir 'Ulwānī dan Jon Armajani. Bandingkan dengan Yūsuf Al-Qaraḍ̄àì, "Qaḍiyah al-Ḥākimiyah wa Āthārathu min Jadal, "Mawqi' al-Qaradāiwi, 12 Desember 2009, http://www.qaradawi.net/articles/862009-12-12-10-35-10/5029-2011-09-25-11-44-39.html,(diakses pada 25 April 2012), Țāhā Jābir'Ulwāni, Hākimiyat al-Qurān (Kairo: al-Ma'had al'Ali li al-Fikri al-Islāmī, 1996), 90 dan Jon Armajani, Modern Islamist Movement (Oxford: John Wiley and Sons, 2012), 58-61.

${ }^{30}$ Sayyid Qutb, Fì Zilāl al-Qur'ān vol.1, 286

${ }^{31}$ Ibn Jarì al-Ṭabarì, Jāmi ‘ al-Bayān fì Ta'wìl Ayi al-Qur'ān (Kairo: Muassasah al-Risālah, 2000), vol. 6, 352 dan al-Baghawì, Ma'ālim al-Tanzīl (Dār al-Ṭaibah, 1997), vol. 2, 27. 
ciri yang dimiliki oleh Muhammad. Oleh karena itu, ketika mereka mengetahui dan menemukan Nabi tersebut, maka wajib bagi mereka untuk beriman. Akan tetapi, kaum Nasrani tersebut menolak untuk beriman, tetapi di sisi lain mereka mengaku sebagai kesayangan Allah. Oleh karena itu, ayat tersebut turun sebagai teguran bagi mereka, bagaimana mungkin orang yang mengaku cinta kepada Allah, tapi tidak cinta kepada Nabi-Nya Muhammad? ${ }^{32}$

Sabab nuzūl ayat tersebut, memperlihatkan bahwa kekafiran mereka (Nașārā Najrān) adalah penolakan yang disertai pengingkaran dalam hal mengikuti Nabi Muhammad. Berdasarkan hal ini, signifikansi yang didapat darinya adalah penolakan yang disertai rasa ingkar lah yang menjadi sebab bagi kafirnya seseorang. Oleh karena itu, makna dari konsep kedaulatan Tuhan dalam ayat adalah akidah dan beraspek imtithāTi.

Adapun penafsiran Quṭ terhadap ayat tersebut, ternyata tidak jauh berbeda dari penafsir lainnya. Pasalnya, ketika ia menafsirkan ayat tersebut, ia mengatakan bahwa cinta kepada Allah tidak hanya dalam ucapan, namun dibuktikan dengan perbuatan. Selain itu, Quṭ juga mengutip penafsiran ibn Kathir serta ibn al-Qayyim al-Jawziyyah (1292 M-1350 M) terhadap ayat tersebut. ${ }^{33}$ Hanya saja, setelah kutipan perkataan ibn al-Qayyim al-Jawziyyah, Quṭb kemudian kembali menegaskan bahwa inti dari kumpulan ayat Q.S. Ali 'Imrān (3): 1-32 adalah keesaan Allah, dan hal itulah yang juga tercermin dalam ayat ini.

Lebih lanjut mengenai konsep keesaan Allah ini, menurut Quṭb esensi dari Islam itu adalah konsep tauhid yang ada di dalamnya. Berangkat dari konsep tauhid inilah setiap peraturan dan perbuatan manusia harus selaras dengan syariat Allah. Dengan kata lain, dari konsep tauhid ini timbullah totalitas dalam pelaksanaan syariat Allah. Konsep tauhid ini, menurut Quṭ, adalah tema sentral dari kumpulan ayat Q.S. Āli 'Imrān (3):1-32. ${ }^{34}$

Membicarakan konsep tauhid menurut Quṭ, memang merupakan dasar dari konsep kedaulatan Tuhan. Oleh karena itu, ketika Quṭb menyinggung konsep kedaulatan Tuhan, konsep tauhid akan selalu mengiringi. Tidak hanya itu, konsep tauhid ini berimplikasi kepada totalitas dalam pelaksanaan syariat Allah. Dan bagi yang tidak mengerjakan hal itu akan terjerumus pada jāhiliyyah

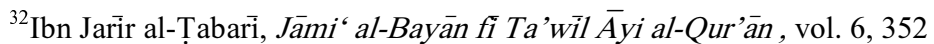

${ }^{33}$ Qutb, Fi Zilāl al-Qur'ān, vol.1, 378

${ }^{34}$ Quṭb, Fì Zilāl al-Qur'ān, vol.1, 378.
} 
modern. Hal itu karena Quṭ, menyatukan konsep kedaulatan Tuhan bermakna akidah dan pemerintahan, antara aspek 'aqdi dengan aspek imtithăli. ${ }^{35}$

Berdasarkan uraian di atas, penulis menyimpulkan bahwa penafsiran Quṭb terhadap ayat Q.S. Āi 'Imrān (3): 32, historis. Meskipun ia menyinggung konsep kedaulatan Tuhan, namun penjelasannya tersebut masih dalam proporsinya, yakni, kedaulatan Tuhan tersebut tidak dibawa kepada maknanya yang siyāsī, namun tetap dalam makna dasarnya.

Kesimpulan di atas didukung pula dengan jika dikomparasikannya penafsiran Quṭb dengan penafsir lainnya. Al-Rāzì dalam tafsirnya mengatakan bahwa dalam ayat Q.S. $\bar{A} \overline{l i}$ 'Imrān (3): 32, Allah menyuruh Nabi Muhammad untuk memberitahukan umatnya bahwa cinta terhadap Allah tidak akan sempurna tanpa ketaatan terhadap Rasul-Nya. ${ }^{36}$ Hal senada juga dikatakan oleh Sayyid Tantāawi (1928 M-2010 M) dalam tafsir al-Wasịt. Menurut mantan syekh Azhar ini, ayat tersebut adalah bukti bagi siapa saja yang beriman serta cinta kepada Allah, maka kecintaannya tersebut belum sempurna tanpa ketaatan terhadap Rasul-Nya. ${ }^{37}$

Adapun detil yang diberikan Quṭb, nampaknya juga tidak mengindikasikan kepada politisasi penafsiran. Pasalnya, Quṭb tidak menyebutkan detil atau penjelasan tambahan yang mengarah kepada aspek pemerintahan. Struktur penafsiran juga mendukung hal itu. Quṭ tatkala menjelaskan ayat tersebut, lebih banyak menjelaskan makna dasar ayat, yakni kewajiban mengikuti perintah Rasul-Nya sebagai bukti dari keimanan seorang muslim kepada Allah. Namun, di akhir penafsirannya Quṭb menyebutkan hikmah yang terkandung dari ayat tersebut, adalah urgensi memahami kalimat al-tawhid dalam kehidupan. ${ }^{38}$

Kedua hal di atas, struktur penafsiran serta detil yang diberikan menunjukkan bahwa tema dalam penafsiran Quṭb, selain kewajiban dalam melaksanakan perintah Allah dan Rasul-Nya, juga diiringi dengan urgensitas konsep tauhid dalam Islam, karena konsep tauhid adalah esensi dari Islam itu sendiri. ${ }^{39}$ Konsep tauhid inilah, sebagaimana yang telah penulis paparkan adalah

${ }^{35}$ John Calvert, Sayyid Qutb and the Origin of Radicalism, 202-203.

${ }^{36}$ Fakhru al-Dìn al-Rāzì, Mafätị̆ al-Ghayb, vol. 4, 178.

${ }^{37}$ Muhammad Sayyid Ṭantāwī, Al-Tafsìr al-Wasịt li al-Qur'ān al-Karīm (Kairo: Nahḍah al-Misr, 1997) vol. 1, 591.

${ }^{38}$ Quṭ, Fi Zilàl al-Qur'ān, vol.1, 378.

${ }^{39}$ Quṭ, Fì Zilàl al-Qur'ān, vol.1, 378. 
dasar bagi konsep kedaulatan Tuhan miliknya. ${ }^{40}$ Namun, dalam ayat ini, menurut penulis penjelasan Quṭb terhadap konsep tauhid ini masih dalam kewajaran dan tidak melampaui makna dasarnya sehingga tidak ahistoris. Begitu juga, penafsiran ini tidak radikal, karena pada ayat ini tidak ada pengkafiran terhadap muslim lainnya.

Contoh-contoh yang telah penulis jelaskan di atas adalah contoh penafsiran Qutb yang historis. Adapaun penafsirannya terhadap konsep kedaulatan Tuhan lainnya bersifat ahistoris. Hal tersebut dapat ditemukan tidak hanya dalam ayat-ayat yang mengandung kata $h-k-m$ saja, tapi juga ayat-ayat lain yang dianggap Quṭb memiliki makna yang sama. Di antaranya adalah Q.S. al-Nisā (4): 51. Ayat ini, turun sebagai pemberitahuan kepada Muhammad atas apa yang dilakukan Yahudi atas dirinya dan Islam. Lebih jelasnya lagi, Huyay ibn Akhtab dan Ka'b al-Ashraf mendatangi kaum Quraish untuk mengajukan kerjasama atas pembunuhan Muhammad pasca kekalahan mereka pada perang Uhud (tahun 3 Hijriah). Ketika itu, Abū Sufyān bertanya dengan rasa heran kepada Ka'b, mengapa mereka (Yahudi) yang notabenenya adalah ahli kitab dan semestinya bersama Muhammad, justru menentangnya. Ka'b pun meminta abu Sufyān untuk menjelaskan agama mereka. Namun setelah itu, Ka'b justru lebih memuji agama abū Sufyān daripada agama yang dibawa Muhammad, padahal mereka tahu bahwa apa yang dibawa Muhammad adalah benar. ${ }^{41}$

Adapun dalam penafsiran Quṭ, terdapat beberapa perbedaan di dalamnya. Pertama mengenai historisitas ayat, memang Quţ menjelaskan makna dasar sekaligus sebab turunnya ayat tersebut. Hanya saja, ketika ia mengkontekstualisasikannya terlihat ketidaksesuaian di sana. Lebih tepatnya, setelah ia menjelaskan makna dasar ayat, ia kemudian menekankan pada arti kata tăghut, yang diartikan Quṭ dengan segala macam peraturan dan hukum yang tidak sesuai dengan syariat Allah. Hal ini tidak ia katakan sekali saja, namun berkali-kali Quṭb mengartikan täghut dengan makna yang mengindikasikan kepada aspek siyāsī. $\bar{i}^{42}$

\footnotetext{
${ }^{40}$ Menurut beberapa peneliti, seperti Youssef Choueiri bahwa konsep kedaulatan Tuhan Qutb, meskipun berasal dari konsep tauhid namun tujuan sebenarnya adalah menjadikan Islam sebagai sistem politik. Bandingkan dengan Sayed Khatab, The Power of Sovereignty: The Political and Ideological Philosophy of Sayyid Qutb (New York: Routledge, 2006),11, Youssef Choueiri, "The Political Discourse of Contemporaryi Islamist Movement," dalam Islamic Fundamentalism, ed. Abdel Salam Sidahmed dan Anoushiravan Ehteshami (Oxford: Westview Press, 1996), 22-26.

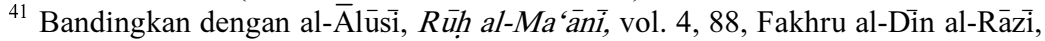
Mafätih al-Ghayb, vol. 5, 232.

${ }^{42}$ Quṭ, Fì Zilàl al-Qur'ān,vol. 2, 681.
} 
Kata tăghüt, menurut penafsir lainnya memiliki banyak makna, sama seperti kata al-jibt. Sebut saja al-Âlūsì, al-jibt ada yang mengartikannya dengan penyihir dan al-tăghüt dengan syetan. Ada juga riwayat lain yang mengatakan bahwa al-taghhut adalah syetan dalam wujud manusia dan al-jibt adalah penyihir. $^{43}$

Menurut penulis, pendapat al-Ṭabari (838 M-923 M) juga sangat cocok dipaparkan di sini. Menurutnya, perbedaan pendapat ini kembali kepada konteks ayat yang membahas al-tăghüt dan al-jibt. Kedua kata tersebut, menurut konteksnya adalah segala sesuatu yang diagungkan selain Allah baik dalam segi ibadah, ketaatan atau ketundukan, yang dapat membuat manusia menyekutukan Allah. Kedua kalimat tersebut dapat disematkan kepada manusia, patung, hewan atau tumbuhan. ${ }^{44}$

Tidak jauh berbeda dengan al-Alūsì, Ibn Kathìr dan Abū Hayyān juga mengatakan bahwa penafsiran țăghüt memiliki banyak definisi. Namun, mereka lebih memilih pendapat yang mengatakan bahwa tăghut adalah yang disembah selain Allah, karena lebih cocok dengan sabab nuzūl ayat tersebut. ${ }^{45}$

Merujuk kamus Lisān al-'Arab, ditemukan bahwa para ahli bahasa membenarkan perbedaan definisi tersebut, karena asal kata daripada tagh $\bar{u} t$ itu sendiri adalah taghā, yang berarti keluar batas. Maka, sah-sah saja jika kata tersebut diartikan sebagai syetan, paranormal atau yang disembah selain Allah. ${ }^{46}$ Hanya saja, apa yang dipilih Quṭ nampaknya tidak mengikuti sabab nuzūl yang ada. Pasalnya, jika merujuk kepada sebab turunnya ayat tersebut, penyebab kekafiran Yahudi adalah pengingkaran mereka akan hukum Allah serta membiarkan para pemuka agama mereka untuk mengganti hukum-hukum Allah sesuai dengan kepentingan mereka sendiri. Adapun Quṭb, ia lebih memilih bahwa arti dari tăghüt, adalah segala peraturan yang tidak berdasarkan shariat

${ }^{43} \mathrm{Al}-\overline{\mathrm{A}} \mathrm{l}$ ūsi,,$R \bar{u} h$ al-Ma ‘ānì, vol. 4, 88

44 Ibn Jarìr al-Ṭabarī, Jāmi ' al-Bayān fí Ta'wīl 'Ayi al-Qur'ān (Kairo: alMaktabah al-Tawfiqiyyah, 2004), 465.

45 Al-Alūsì, Rūḥ al-Ma'ānī (Beirut: Dār al-Iḥyā', tth), 884 dan Abū Hayyān, Bahru al-Muhịt (Dār al-Kutub, 2005), 156. Menurut peneliti, pendapat al-Alūsì lebih mudah dipahami. Ia mengatakan bahwaasal kata al-jibt adalah sebuah nama untuk berhala yang kemudian digunakan untuk segala sesuatu yang disembah selain Allah. Adapun al-tăghüt asal katanya ditujukan untuk segala sesuatu yang batil, yang disembah sebagai Tuhan selain Allah. Ada juga riwayat lain yang mengatakan bahwa al-jibt adalah penyihir dan al-tâghu $\bar{t}$ adalah syetan, dan pendapat-pendapat lainnya. Adapun yang dimaksud dengan beriman kepada keduanya adalah menganggap keduanya - baik al-jibt ataupun al-țagh $\bar{u} t$ sebagai Tuhan, dan makna terakhir inilah yang paling bisa diterima sesuai dengan siyāq al-āyat.

${ }^{46}$ Ibn Manzūur, Lisān al- 'Arab, vol. 15, 7. 
Allah, tanpa memberikan detil lebih lanjut, ketidaktaatan yang bagaimana yang dapat menyebabkan kekafiran. Maka berdasarkan ini, penulis menyimpulkan bahwa parameter dari definisi yang diambil Quṭ, adalah sisi linguistik dari kata tersebut, yaitu taghā yang berarti keluar batas. Oleh karena itu, ia kemudian mengambil kesimpulan bahwa segala sesuatu yang tidak mengikuti syariat Allah berarti taghüt, karena keluar dari batas syariat. ${ }^{47}$

Uraian di atas, menandakan bahwa penafsiran Quṭb terhadap kata altăghüt adalah ahistoris. Kesimpulan tersebut, didukung dengan penafsiran mengenai "beriman kepada al-jibt dan al-țaghhüt."Al-Ālusi dalam tafsirnya $R \bar{u} h$ al-Ma'ānì mengatakan bahwa terdapat beberapa kemungkinan dalam menafsirkan kalimat "beriman kepada keduanya." Kendati demikian, makna yang tepat dalam mengartikan beriman kepada al-jibt dan al-tăghüt, adalah meyakini ketuhanan mereka serta beribadah kepada keduanya sehingga berujung kepada penyekutukan Allah. Dengan ini, penulis menyimpulkan bahwa signifikansi yang diambil Qutb dalam ayat di atas tidak cocok dengan konteks ayat atau bersifat ahistoris, karena tidak terhubung dengan sebab turunnya ayat. Quṭb hanya mengambil keduanya-al-jibt dan al-țăhut - sebagai perbuatan yang tidak sesuai dengan syariat, tanpa mempertimbangkan bagaimana kaum Yahudi dan Nasrani menuhankan keduanya. Hal ini lah yang menjadikan penafsiran Quṭb kali ini bersifat ahistoris sekaligus ideologis. ${ }^{48}$

Hal ini didukung dengan pemberian detil yang kurang tatkala menjelaskan makna tăghüt. Quṭb hanya menjelaskan bahwa definisi tăgh $\bar{u} t$ adalah segala peraturan yang tidak berdasarkan syariat Allah. Padahal, ia menceritakan sebab Yahudi yang menjadi kafir yakni sikap yang menjadikan para pendeta mereka seperti Tuhan. Jika ditarik signifikansi dari ayat tersebut, terlepas dari perbedaan pendapat mengenai definisi tăgh $\bar{u}$, maka karakteristik dari sifat Yahudi adalah pengingkaran atas shariat dan hukum Allah, akan tetap terjaga walaupun ayat tersebut dibawa ke masa kini. Namun, dalam pengertian tăghüt kali ini, tidak ditampakkan detil yang menjelaskan hal tersebut. ${ }^{49}$

${ }^{47}$ Quṭb, Fì Zilāl al-Qur'ān, vol 2, 681.

48 Quṭ, dalam penafsiran tersebut telah menggabungkan antara "pemujaan berhala" yang dalam bahasa al-Qur'an adalah țaghüt dengan "pemerintahan tirani." Oleh karena itu, tidak heran jika Quṭb sering menyebut pemerintahan tirani dengan tăghüt. Dan ini adalah salah satu bukti ideologiasasi yang dilakukan Qutb. Bandingkan dengan Roxanne L. Euben, Musuh dalam Cermin, penerjemah Satrio Wahono (Jakarta: Serambi Ilmu Semesta, 2002), 125, Dale F. Eickelmen dan James Piscatori, Ekspresi Politik Islam, penerjemah Rofik Suhud (Bandung: Mizan, 1998), 55 dan Quṭb, Fï Zilāl alQur'ān, vol 2, 81.

${ }^{49}$ Quṭb, Fì Zilāl al-Qur'ān, vol 2, 681-682. 
Berangkat dari kata al-tăghüt inilah, konsep kedaulatan Tuhan dalam penafsiran Quṭb diartikan kepada aspek pemerintahan, sehingga penafsiran tersebut cenderung ideologis. Lebih jelasnya, konteks ayat Q.S. al-Nisā (4): 51 bertemakan tauhid sehingga konsep kedaulatan Tuhan dalam ayat tersebut seharusnya memiliki aspek akidah. Namun konsep kedaulatan Tuhan dalam ayat tersebut, lebih mengarah kepada aspek siyāsiyyah. Hal ini, menjadi bukti kuat bahwa penafsirannya bersifat ahistoris dan ideologis. ${ }^{50}$

Bukti lain akan hal tersebut terlihat ketika Quṭb menjadikan apa yang dilakukan Yahudi masa kini, tidak berbeda dengan apa yang dilakukan pendahulunya, yakni menjadikan orang kafir sebagai sekutu untuk sama-sama menjatuhkan Islam. Quṭ mengatakan bahwa pada masa kini, Yahudi semakin cerdas dalam menjatuhkan Islam. Mereka menggunakan media massa untuk menjatuhkan gerakan-gerakan Islam yang dinilai berhasil dalam mengajak manusia kepada syariat-Nya. ${ }^{51}$

Jika ditelisik lebih jauh mengenai apa yang dialami oleh Quṭ pada masanya, penafsiran Quṭ tersebut dipengaruhi dengan apa yang ia alami pasca revolusi. Pasca revolusi 1952 terjadi, pemerintahan republik Mesir saat itu, tidak menginginkan syariat Islam menjadi sistem negara sebagaimana yang diusulkan gerakan ikhwān al-muslimūn. Akan tetapi pemerintah terpilih justru menjadikan Yahudi-yakni Israel dan Amerika - sebagai sekutu. Terlebih lagi setelah adanya penolakan Näjib dan Nasser atas saran dari gerakan ikhwān almuslimūn. Selain itu, pemerintahan republik yang merasa terancam dengan eksistensi IM khususnya pasca percobaan pembunuhan akan Nasser, pemerintah memenjarakan banyak anggota IM serta memboikot gerakan mereka sehingga gerakan ini tidak diperbolehkan lagi beroperasi. Pemerintah juga menggunakan media massa untuk mendukung setiap gerakan mereka. ${ }^{52}$

Gambaran dari kejadian ini, sangat terlihat dalam penafsiran Quṭ. Meskipun ia tidak menyebutkan secara detil peristiwa tersebut, namun apa yang dituangkan ke dalam tafsirnya cukup mewakili apa yang dialami. Bahkan, menurut beberapa peneliti konsep kedaulatan tersebut didominasi oleh peristiwa

${ }^{50}$ Quṭb, Fì Zilāl al-Qur'ān, vol 2, 682 dan Hishām Ja'far, al-Ab'ād al-Siyāsiyyah li Mafhūm al-Hākimiyyah, 74.

${ }^{51}$ Quṭb, Fì Zilàl al-Qur'ān, vol 2, 682

${ }^{52}$ Bandingkan dengan John Calvert, Sayyid Qutb and the Origin of Radicalism, 202-203, R. Hrair Dekmejian, Islam in Revolution Fundamentalism in The Arab World, 91-92 dan Emmanual Sivan, Radical Islam: Medieval Theology and Modern Politics (London: Yale University Pres), 40-41. 
yang ia alami, yakni, kognisi sosial Quṭ merupakan sumber primer dan bukan pengaruh al-Mawdūdi (1903-1979 M). ${ }^{53}$

Adapun dalam segi struktur penafsiran, terlihat bahwa Quṭ mengawali penafsirannya dengan menjelaskan makna tăghut tidak dengan al-jibt, berbeda dengan ulama lainnya yang menjelaskan kedua kosa kata tersebut bahkan menjelaskan perbedaan pendapat dalam mengartikan keduanya. Ini membuktikan, bahwa Quṭb terlihat menekankan kata tăghüt, selain dari keengganannya menuliskan perdebatan dalam penafsirannya. Meskipun demikian, Quṭb terlihat sesekali menyebutkan bahwa orang yang mengikuti tăghüt serta "beriman" kepadanya, itulah yang disebut kafir. Namun yang penulis sayangkan di sini, hal tersebut tidak dilakukan secara merata, sehingga efek yang ditimbulkan adalah hanya penekanan pada makna tag $\bar{g} \bar{u} t$, yakni yang tidak menjalankan shariat Allah secara umum. Hal ini, dapat menjadikan legitimasi bagi gerakan-gerakan radikal. ${ }^{54}$

Berdasarkan struktur penafsiran, detil dan latar yang digunakan, penulis menyimpulkan bahwa penafsiran Quṭb kali ini selain ahistoris, juga ideologis. Dalam penafsiran tersebut, terlihat pula ketidaksukaan Quṭ terhadap pemerintah yang menjadikan Yahudi sekutu. Selain itu, ia juga menyebut pemerintahan tersebut dengan sebutan tăghüt. Hal ini menandakan bahwa penafsirannya bersifat politis. ${ }^{55}$ Kendati demikian, penulis belum menemukan leksikon yang mengindikasikan kepada pengkafiran atau seruan untuk memboikot pemerintahan tersebut, sehingga, menurut penulis penafsiran terhadap ayat di atas bersifat ahistoris dan ideologis, namun belum mencapai tingkat radikal.

Contoh di atas adalah penafsiran Quṭb yang ahistoris namun bukan pada ayat yang terdapat kata $h-k-m$ di dalamnya. Berikut ini, akan penulis paparkan contoh lain yang terdapat kata $h-k-m$, yaitu pada rangkaian ayat al-Mā'idah (5): 41-50. Lebih jelasnya, sebagaimana metode Qutb dalam menafsirkan ayat, ia

\section{5.}

${ }^{53}$ Bandingkan dengan John Calvert, Sayyid Qutb and the Origin of Radicalism,

${ }^{54}$ Salah satunya adalah gerakan radikal yang timbul setelahnya seperti al-Takfir wa al-Hijrah, jamā'at al-Jihād dan al-Qaeda. Bandingkan dengan Quṭ, Fì Zilāl alQur'an, vol. 2, 682, R. Hrair Dekmejian, Islam in Revolution Fundamentalism in The Arab World, 94 dan Jon Armajani, Modern Islamist Movement, 62-65.

${ }^{55}$ Qutb sering menyebut pemerintahan yang tirani dengan kata tăghüt. Dengan kata lain, ia telah menggeser makana tăgh $\bar{u}$, dari penyembah berhala ke pemimpin yang tirani. Dan salah satu contoh pemerintahan tirani menurut Quṭ adalah pemerintahan Fir'aun. Lihat James Piscatori, Ekspresi Politik Islam, penerjemah Rofik Suhud (Bandung: Mizan, 1998), 81. 
selalu memberikan penjelasan umum untuk setiap rangkaian ayat, begitu juga pada ayat-ayat al-Māidah ini. Namun ada beberapa hal yang berbeda dengan penafsirannya yang lain. Pertama, dalam pengantarnya tersebut Quṭ menjelaskan bahwa rangkaian ayat-ayat ini menceritakan perkara yang sangat penting, yaitu hal-hal yang menyangkut dengan akidah. Dari konsep ini terdapat sistem yang mengatur kehidupan manusia yaitu syariat Islam. Maka, syariat yang mengatur kehidupan manusia berangkat dan berasal dari konsep akidah. Dengan kata lain, menurut Quṭb, sudah sepantasnya jika segala peraturan yang mengatur kehidupan manusia berdasarkan syariat Allah dan bukan yang berlawanan dengan syariat-Nya, karena kedaulatan mutlak hanya pada Allah. ${ }^{56}$

Penafsiran Quṭ di atas, menggambarkan bahwa Quṭ menekankan pada konsep kedaulatan Tuhan. Untuk menjelaskannya, Quṭb pada penafsiran sebelumnya memulainya dengan konsep akidah dalam Islam serta karakteristiknya yang shumūl (komprehensif), maka segala peraturan dan hukum yang mengatur perilaku manusia sudah sepantasnya berdasarkan syariat Allah. Hal ini, kemudian diperjelas oleh Quṭb dengan pengkategorian muslim atau kafir. Yakni, Quṭ setelah menerangkan hubungan antara akidah dengan syariah, ia menjelaskan bahwa karena islam itu mencakup segala aspek, maka penerapan konsep kedaulatan Tuhan di Bumi-dengan menjalankan syariatNya-berhubungan dengan kafir atau muslimnya seseorang. ${ }^{57}$

Tujuan Qutb tersebut makin terlihat tatkala ia menjelaskan lebih dalam konsep kedaulatan tersebut. Qutb menerangkan apa yang ia tulis mengenai pengkategorian antara Islam dengan kafir, Islam dengan jahiliyah, syariat dan hawa nafsu manusia. Menurutnya, muslim adalah mereka yang menjalankan syariat Islam dan hukum-hukumnya, sedangkan kafir, fasik dan zalim adalah mereka yang tidak menjalankannya. Kategori kedua ini terbagi menjadi dua kategori. Pertama, para hakim dan kedua rakyat sipil yang berada di bawah

${ }^{56}$ Quṭb, Fỉ Zilāl al-Qur'ān, vol. 2, 682.

${ }^{57}$ Konsep kedaulatan Tuhan dalam teori Quṭb, adalah perluasan dari konsep akidah. Yang jika diperinci, merupakan kelanjutan dari konsep ulühiyah yang diartikan dengan kedaulatan, rubübiyah, rabbāniyah yang diartikan dengan ketuhanan dan kekuasaan. Hal ini sebenarnya bukan masalah selama Quṭb tidak mencampuradukkan konsep akidah tersebut dengan pelaksanaan syariat. Sehingga semua yang tidak menjalankan hukum Allah dianggap seperti menolak kedaulatan-nya. Akibat dari konsep kedaulatan Tuhan ini, adalah pengkategorian manusia menjadi kafir, muslim, Islam dan jahiliyah, syariat atau hawa nafsu. Bandingkan dengan R. Hrair Dekmejian, Islam in Revolution Fundamentalism in The Arab World, 91, John Calvert, Sayyid Qutb and the Origin of Radicalism , 207-209 dan Roxanne L. Euben, Musuh dalam Cermin, penerjemah Satrio Wahono (Jakarta: Serambi Ilmu Semesta, 2002), 119-120. 
kuasa mereka. Bagi Quṭb, baik hakim maupun masyarakatnya yang tidak menjalankan syariat dan hukum Allah, serta masyarakat yang tidak menerima keputusan hakim yang berdasarkan syariat Allah masuk dalam golongan kafir, fasik dan zalim. Sedangkan para hakim yang menjalankannya, begitu juga rakyat mereka yang menerima keputusan hakim yang memutuskan berdasarkan syariat, maka mereka masuk dalam kategori muslim. ${ }^{58}$

Berdasarkan penjelasan di atas, penulis menyimpulkan bahwa tema yang diusung Quṭ dalam rangkaian ayat Q.S. al-Māidah (5): 41-50 adalah konsep kedaulatan Tuhan. Dari apa yang ditulis Quṭb tersebut, terlihat pengaruh dari keadaan sosial politik yang ia rasakan. Lebih jelasnya, Quṭ yang berjuang bersama anggota IM untuk menjadikan syariat Islam sebagai sistem politik Mesir saat itu, harus berbenturan dengan pemerintahan baru Republik Mesir yang dahulu mereka bantu dalam melakukan revolusi penggulingan pemerintahan monarki saat itu. Pemerintah dengan tegasnya menolak saran yang diberikan Quṭ dan IM. Mereka lebih memilih mengadopsi sistem sekular daripada syariat Islam. Ditambah lagi, siksaan yang diterima Quṭb dan anggota IM lainnya pasca perbedaan pendapat antara kedua kekuatan tersebut, membuat Quṭ yakin bahwa Nasser beserta rezim pemerintahan saat itu berada dalam lembah jahiliyah modern lantaran telah menolak kedaulatan Tuhan yang absolut. Sesuai dengan bunyi Q.S. al-Mā'idah (5): 44, mereka adalah kafir. ${ }^{59}$

Quṭb memberikan banyak detil dalam penafsiran ini. Hal tersebut dimulai dengan kekuasaan Allah yang mutlak, dilanjutkan dengan keutamaan syariat Islam. Kemudian, penjelasan tersebut dihubungkan kepada konsep hăkimiyyah, karena konsep kedaulatan Tuhan tersebut hanya bisa diterapkan

58 Akibat dari konsep kedaulatan Tuhan ini, adalah pengkategorian manusia menjadi kafir, muslim, Islam dan jahiliyah, syariat atau hawa nafsu. Karena menurut Quṭ, pengkategorian berdasarkan ras sebagaimana yang timbul dari "nasionalisme" serta Pan Arabisme" hanya mengkotak-kotakkan muslim dan mencerai-beraikannya. Sedangkan Allah dan Muhammad menyeru kepada kesatuan umat tanpa perbedaan, karena yang membedakan hanya takwa. Bandingkan dengan John Calvert, Sayyid Qutb and the Origin of Radicalism, 207-209. Sayyid Quṭ, Fì Ziläl al-Qur'ān, vol. 2, 367.

${ }^{59}$ Sayyid Quṭ, Fì Zilāl al-Qur'ān, vol. 2, 888, Hishām Ja'far,"Manhaj al-Nazar ilā Mafhūmayy al-Ḥākimiyah wa al-Jāhiliyah,"onislam (10 Agustus 2010), http://www.onislam.net/arabic/madarik/concepts/90810-2010-08-09-071215.html

(diakses pada 6 April 2014) John Calvert, Sayyid Qutb and the Origin of Radicalism, 203, AB. Rahman, Nooraihan Ali dan Wan Ibrahim, "The Influence of al-Aqqād and Dî̀ān School of Poetry on Sayyid Quṭ's Writings" International Journal of Humanities and Social Science 8, vol. 1 (Juli 2008): 158, www.ijhssnet.com/journals/Vol._1No._8; July_2011/18.pdf (diakses pada 15 Januari 2014 
jika syariat Islam telah diaktualisasikan. Jika membandingkan hal ini dengan penafsiran yang sebelumnya, terlihat adanya perbedaan. Pasalnya, pada penafsiran sebelumnya Quṭ tidak memberikan detil begitu banyak hanya untuk menerangkan konsep hākimiyyah, berbeda dengan penafsirannya kali ini. Hal ini menandakan bahwa ayat al-Mā'idah adalah ayat utama dalam menafsirkan konsep hăkimiyyah. Di dalamnya, Quṭb dengan panjang lebar menjelaskan konsep kedaulatan Tuhan tersebut mulai dari konsep dasar, yakni konsep tauhid hingga berlanjut kepada tatatan praktik. Tidak hanya itu, ia juga menjelaskan makna dari "jahiliyah modern" yang kini banyak mewabah di dunia modern, bahkan di negara yang mayoritas warganya muslim. ${ }^{60}$

Lebih jelasnya mengenai detil yang diberikan, terlihat ketika Quṭ menjelaskan konsep kedaulatan Tuhan dalam penafsiran umumnya terhadap Q.S. al-Mā'idah (5): 41-50 ini. Ia menjelaskan bahwa syarait Islam bersifat komprehensif. Selain itu, ia juga memiliki karakteristik berupa ulūhiyyah, rubübiyyah dan rabbāniyyah. Maka ketika syariat Islam ini ada dalam setiap lini kehidupan, maka ia adalah seorang muslim sejati. Begitu juga sebaliknya, jika tidak menjalani syariat Islam secara komprehensif, maka hal ini berarti penolakan terhadap syariat-Nya, baik datangnya dari perbuatan, atau hanya dengan lisannya. ${ }^{61}$

Apa yang dikatakan Quṭb di atas, terlihat mengambang. Generalisasi yang ia lakukan tatkala menjelaskan definisi dari penolakan terhadap syariat islam, yang tidak lain adalah penolakan terhadap kedaulatan Tuhan, dapat membuat kesalahpahaman dalam memahami kedaulatan Tuhan. Hal ini, karena terdapat banyak alasan ketika seorang muslim tidak menjalani syariat Islam.

${ }^{60}$ Quṭb, Fì Zilāl al-Qur'ān, vol. 2, 888-889. Adapun mengenai konsep jahiliyah modern, sangat berhubungan dengan konsep kedaulatan Tuhan. Karena selama sebuah komunitas atau individu belum menjalankan totalitas dalam syariat Allah, maka mereka berada dalam sebuah kejahiliyahan modern, yang bahkan lebih buruk dari jahiliyah praIslam. Tidak hanya itu, menurut Qutb, jahiliyah modern tersebut selain disematkan bagi sebuah negara atau sistem yang berseberangan dengan syariat Allah dan lebih memilih sistem buatan manusia, kata tersebut juga disematkan untuk ahli kitab, Yahudi dan Nasrani, dan terakhir disematkan kepada masyarakat komunis. Konsep jahiliyah modern maupun kedaulatan Tuhan, menurut beberapa peneliti berkembang sejak Qutb berada di Amerika, kemudian semakin berkembang saat ia dipenjara. Bandingkan dengan Ahmad S. Moussalli, The Islamic Quest for Democracy, Pluralism, and Human Rights (Florida: university Press of Florida, 2003),64-65, John L. Esposito, The Islamic Threat: Meat or Reality, 137 Tauseef Ahmad Parray, "Operational Concept of Islamic Democracy: Khilāfah, Shūra, Ijma' and Ijtihad," Journal of Humanity and Islam vol. 1, no. 1 (2011): 22-23, http://www.hgpub.com/index files/jhi/pdf2011/jhi.2231-

7252.2011.0101.1127.2.pdf (diakses pada 05 Maret 2014).

${ }^{61}$ Quṭb, Fì Zilāl al-Qur'ān, vol. 2, 889 
Oleh karena itu, sebagian peneliti mengatakan bahwa membaca penafsiran Quṭb terhadap konsep kedaluatan Tuhan, diperlukan kajian yang lebih lanjut mengenai kognisi sosial yang ia hadapi. Hal ini karena apa yang ia tulis, jika ditelisik lebih jauh merupakan buah dari kekerasan dan siksaan yang ia terima dari pemerintah yang berkuasa. ${ }^{62}$

Generalisasi yang ia lakukan akan terlihat lebih jelas ketika Quṭb masuk ke dalam penafsiran terperinci terhadap ayat Q.S. al-Mā'idah (5): 44. 45. 47. Lebih jelasnya, tatkala Quṭb menerangkan Q.S. al-Mā'idah (5): 44, ia menafsirkan bahwa kata "kāfir" tersebut disematkan bagi semua yang tidak menjalankan hukum dan syariat Allah. Adapun penyebabnya, masih menurut Qutb, adalah tidak dilaksanakannya hukum Allah sama saja dengan menolak ketuhanan Allah. ${ }^{63}$

Pada penafsiran Quṭ di atas, terlihat bahwa ia menggeneralisir definisi orang yang kafir dalam ayat tersebut. Ia tidak menjelaskan lebih lanjut penolakan yang bagaimana yang menjadikan ia kafir, karena konsep kedaulatan Tuhan itu sendiri memiliki dua aspek, teori dan praktik. Namun Quṭb dalam menjelaskan hal tersebut tidak menjelaskannya lebih detil. Ia menggeneralisir hal tersebut sehingga implikasinya adalah, pemahaman bahwa setiap yang tidak menjalankan hukum Allah adalah kafir. ${ }^{64}$

Lebih jelasnya mengenai generalisasi tersebut, terlihat ketika dikomparasikannya penafsiran Quṭb dengan penafsir lainnya. Pertama,

${ }^{62} \mathrm{Di}$ antaranya adalah Hassan Hanafi (1. $\left.1935 \mathrm{M}\right)$. Menurutnya, konsep kedaulatan Tuhan Quṭb bukanlah khitāa dinīi, melainkan siyāsi. Karena di dalam konsep kedaulatan Tuhan tersebut, telah banyak dipengaruhi oleh kondisi sosial politik Quṭ saat itu. Oleh karenanya, dalam memahami konsep ini pun, diperlukan tidak cukup hanya dengan analisis teks semata, mealinkan diperlukan pula analisis terhadap kondisi sosial politik yang terjadi saat itu. Tidak berbeda dengan Hanafí, abū Zayd (1943-2010) juga mengatakan hal yang sama. Menurutnya, apa yang ia alami pada tahun 50-an dan 60-an telah mewarnai pemikirannya, khususnya mengenai konsep kedaulatan Tuhan ini. Bandingkan dengan Naṣr Ḥāmid abū Zayd, Naqd al-Khitāāb al-Dỉnī (Beirut: al-Markaz alThaqafí al-'Arabì, 2007), 126 dan Ḥassan Ḥanafí, Ḥiwār al-Ajyāl (Dār al-Qubā': 1998), 474 ,

http://books.google.co.id/books?id=327IhhnJ6kC\&dq=\%D8\%AD\%D8\%B3\%D9\%86+ \%D8\%AD\%D9\%86\%D9\%81\%D9\%8A+\%D8\%A7\%D9\%84\%D8\%AD\%D8\%A7\%D9\% 83\%D9\%85\%D9\%8A\%D8\%A9+\%D9\%82\%D8\%B7\%D8\%A8\&hl=id\&source=gbs navl inks_s (diakses pada 6 April 2014).

${ }^{63}$ Quṭ, Fì Zilāl al-Qur'ān, vol. 2, 896-900.

${ }^{64}$ Bandingkan dengan Hishām Ja'far, al-Ab'ād al-Siyāsiyah li Mafhūm alHākimiyyah, 55 dan Hishām Ja’far,"Manhaj al-Naẓar ilā Mafhūmayy al-Hākimiyah wa al-Jāhiliyah," onislam (10 Agustus 2010), http://www.onislam.net/arabic/madarik/concepts/90810-2010-08-09-071215.html (diakses pada 6 April 2014). 
mengenai sebab turunnya ayat. Mengutip perkataan ibn Jarir, bahwa ayat tersebut diturunkan pada saat beberapa Yahudi bertanya kepada Nabi Muhammad tentang hukuman orang yang berzina yang telah menikah. Nabi menjawab bahwa hukumannya adalah rajam, namun pemuka agama Yahudi tersebut menolak dan mengatakan bahwa dalam Taurat hukuman bagi pezina yang telah menikah adalah dihitamkan mukanya dan diarak. Padahal, hukuman sebenarnya adalah rajam, sama dengan apa yang diberitahukan Muhammad. Oleh karena itu, Yahudi tersebut dinyatakan telah kafir lantaran mengganti hukum Allah dengan yang lainnya. ${ }^{65}$

Signifikansi yang dapat diambil, bahwa ayat tersebut meskipun diturunkan kepada Yahudi, namun jika menggunakan kaidah al-'ibrah bi 'umūm al-lafž, maka individu dalam ayat tersebut dapat diperluas dengan menjaga sebabnya, yaitu menolak hukum Allah serta menggantinya dengan yang lain, dengan alasan ingkar. ${ }^{66} \mathrm{Hal}$ ini semakin diperjelas dengan penafsiran al-Âlūsi (1802 M-1854 M) terhadap kata "al-kāfirūn."

Al-Alūsì dalam tafsirnya Rụh al-Ma'añi menjelaskan bahwa ayat tersebut digunakan kelompok khawarij untuk mengkafirkan semua yang tidak menjalankan hukum Allah. Hal ini menurutnya adalah sebuah kesalahpahaman, karena meskipun lafaz "ḥukm" mencakup semua amalan baik amalan hati atau perbuatan, akan tetapi yang dimaksud di sini adalah amalan hati. Begitu juga dengan lafaz "man," meskipun ia bersifat umum namun keumuman tersebut dikhususkan dengan sebab turunnya ayat. Maka, kategori kafir dalam ayat tersebut, diperuntukan bagi mereka yang menolak hukum Allah dengan hati, atau dengan kata lain ingkar terhadap syariat-Nya. ${ }^{67}$

Adapun Quṭb, ia menggunakan lafaz "man" sebagai dalil untuk megumumkan kategori kafir kepada semua yang tidak menjalankan hukum Allah. Padahal, penafsir lainnya memberikan detil yang lebih lanjut mengenai kategorisasi kafir dalam ayat Q.S. al-Mā'idah (5): 44. Seperti al-Âlūsī, ibn 'Āshūr (1879 M-1973 M) dalam tafsirnya al-Tahrïr wa al-Tanwïr, juga menjelaskan bahwa ayat tersebut tak bisa diartikan secara umum, yakni dengan menggeneralisir semua yang tidak menjalankan hukum Allah adalah kafir, seperti yang dilakukan khawārij, karena terdapat banyak alasan ketika seorang

${ }^{65}$ Ibn Jarìr al-Ṭabarī, Jāmi ‘ al-Bayān fỉ Ta’wìl Ayyi al-Qur'ān, vol. 10, 345.

${ }^{66}$ Lihat Qașabì Maḥmūd Zallāt, 'Ulūm al-Qur'ān (Dubai: Dār al-Qalam, 1987), 52 dan Hishām Ja'far,"Manhaj al-Naẓar ilā Mafhūmayy al-Hākimiyah wa al-Jāhiliyah," onislam (10 Agustus 2010), http://www.onislam.net/arabic/madarik/concepts/908102010-08-09-071215.html (diakses pada 6 April 2014).

${ }^{67}$ Bandingkan dengan al-Âlūsì, Rūḥ al-Ma ānì, vol. 4, 500. 
Muslim tidak menjalankan hukum Allah. Oleh karenanya, makna ayat tersebut dikembalikan kepada sebab turunnya ayat, yakni penolakan yang dilakukan Yahudi atas penerapan hukum Allah. Maka, dengan ini mereka yang disebut kafir oleh ayat ini adalah yang menolak hukum Allah dengan hati, atau dengan kata lain mengingkari hukum dan syariat Allah sebagaimana yang dilakukan Yahudi. $^{68}$

Apa yang dipaparkan al-Âlūsỉ dan ibn 'Āshūr adalah contoh penafsir yang memberikan detil untuk menjelaskan siapa yang termasuk kafir dalam Q.S. al-Mā'idah (5): 44 tersebut. Namun Quṭb tidak memberikan detil tersebut sehingga menimbulkan kerancuan dalam memahami ayat tersebut. Generalisasi itu pun kembali terlihat dalam penafsiran ayat selanjutnya. Pada Q.S. alMā'idah (5): 45, Quṭb mengatakan bahwa predikat zalim di dalamnya adalah sifat tambahan selain sifat kafir. Lebih jelasnya, mereka disebut kafir karena telah meninggalkan hukum Allah, dan disebut zalim karena mereka mengajak manusia lainnya kepada hukum manusia. ${ }^{69}$

Penafsiran Quṭb di atas jika dikomparasikan dengan penafsir lainnya terdapat kejanggalan. Al-Ālūsī misalnya, meskipun ia meyebutkan pendapat lain yang berbunyi, bahwa ketiga sifat tersebut—kafir, zalim dan fasik—ada yang menyematkannya pada satu golongan saja, yakni mereka yang dianggap kafir dalam Q.S. al-Mā'idah (5): 44, namun ada sedikit perbedaan dengan apa yang disampaikan Quṭb. Yakni, yang dimaksudkan kafir, fasik dan zalim adalah mereka yang meninggalkan hukum Allah yang disertai dengan pengingkaran. Hal itu menurut al-Alūsī, karena selain mereka tidak mengingkari hukum Allah, mereka juga mengajak manusia lainnya untuk meninggalkan hukum Allah, sehingga disebut dengan orang yang fasik dan zalim. ${ }^{70}$ Namun Quṭ, masih menggeneralisir sifat zalim tersebut sama ketika ia menggeneralisir kata kafir. Dan hal ini masih berlanjut sampai Quṭ menjelaskan sifat ketiga, yaitu fasik dalam Q.S. al-Mā'idah (5): $47 .{ }^{71}$

Berdasarkan uraian di atas, penulis menyimpulkan bahwa penafsiran Quṭb terhadap ayat Q.S. al-Mā'idah (5): 44, 45 dan 47 bersifat ahistoris. Pasalnya, Quṭb menjelaskan konsep kedaulatan Tuhan tidak sesuai dengan sebab turunnya ayat. Penafsiran tersebut juga bersifat ahistoris, karena ayat tersebut memiliki konsep kedaulatan Tuhan bermakna akidah, namun Quṭb 4, 207.

${ }^{68}$ Lihat ibn 'Āshūr, al-Tahrīir wa al-Tanwìr (Tunisia: Dār al-Ṣaḥnūn, 1965), vol.

${ }^{69}$ Quṭ, Fï Zilāl al-Qur'ān, vol. 2, 897.

${ }^{70}$ Al-Alūsì, Rūh al-Ma'ānì, vol.4, 500.

${ }^{71}$ Quṭb, Fì Zilàl al-Qur'ān, vol. 2, 375. 
mengartikannya dengan maknanya yang siyāsî. Selain itu, penafsirannya kali ini mengindikasikan kepada pemikiran yang radikal. Karena di dalam tulisannya tersebut, Quṭb menyatakan setiap yang tidak menjalankan hukum Allah adalah kafir. Penafsirannya ini, menjadi legitimasi atas tindakan radikal yang timbul setelahnya. $^{72}$

Kesimpulan tersebut didukung dengan kosa kata (leksikon) yang digunakan. Dalam menjelaskan konsep hăkimiyyah kali ini, ia banyak menggunakan kata-kata yang kontras, seperti ïmān-kufr, Isläm-jāhiliyyah, shar'un-hawā. Sedangkan pada penjelasan sebelumnya, ia tidak memakai kata tersebut saat menerangkan konsep hākimiyyah. Efek dari penggunaan kata-kata yang kontras ini, dapat membuat pembaca kepada pengkafiran satu sama lain, apalagi jika tidak membacanya dengan teliti dari segi historisitas ayatnya. ${ }^{73}$

Adapun mengenai struktur penafsirannya, Quṭb sebelum menjelaskan ayat al-Mā'idah (5): 41-50 secara terperinci ia mengatakan bahwa ayat-ayat tersebut memiliki esensi yang sama, yaitu menjelaskan konsep kedaulatan Tuhan. Konsep kedaulatan Tuhan ini tidak lain berasal dari konsep tauhid. Oleh karenanya, siapa saja yang tidak menjalankan hukum Allah berarti kafir, juga fasik dan zalim, tanpa memberikan detil yang lebih mengenai hal tersebut. Melihat struktur penafsiran, detil dan leksikon yang digunakan, terlihat bahwa Qutb menjadikan konsep kedaulatan Tuhan sebagai tema sentral dari ayat-ayat tersebut. $^{74}$

${ }^{72}$ Konsep kedaulatan Tuhan ini adalah dasar ideologi gerakan Islam radikal. Implikasi dari hal ini, adalah penolakan terhadap negara sekular serta gerakan jihad untuk menumbangkan negara jahiliyah, dan menggantinya dengan negara Islam. Bandingkan dengan David Sagiv, Fundamentalism and Intellectuals in Egypt 1973-1993 (London: Frank Cass and CO. LTD, 1995), 50-51, Husain Haqqani, "Islamists and Democracy: Cautions from Pakistan," Journal of Democracy vol. 24, no. 2 (April 2013): 11-13, http://www.journalofdemocracy.org/sites/default/files/Haqqani-24-2.pdf (diakses pada 5 Maret 2014) dan Khaled Abou el-Fadl, "Islam and Challenge of Democratic Commitment," Fordham International Law Journal vol. 27 no. 1 (2003): 13-14, http://ir.lawnet.fordham.edu/cgi/viewcontent.cgi?article=1911\&context=ilj (diakses pada 5 Maret 2014).

${ }^{73}$ Menurut van Dijk, dibalik pemilihan suatu leksikon, terdapat ideologiasi penulisnya. Oleh karena itu, dengan melihat pilihan kata yang digunakan, ideologisasi dapat diungkapkan. Teun van Dijk, Ideology and Discourse, 55, http://www.discourses.org (diakses pada 12 Desember 2013).

${ }^{74}$ Quṭb, Fì Zilāl al-Qur'ān, vol. 2, 375 


\section{Penutup}

Berdasarkan uraian-uraian di atas, terlihat bahwa penafsiran ayat-ayat tersebut tidak semuanya bersifat ahistoris dan radikal. Namun dalam tulisan ini, penulis hanya menjelaskan beberapa contoh saja sebagai representasi dari kategori penafsiran ayat historis, ahistoris-tidak radikal dan ahistoris-radikal. Adapun kesimpulan penulis secara keseluruhan dalam tulisan adalah sebagai berikut; pertama, penafsiran ketujuh belas ayat tersebut tidak semuanya bersifat ahistoris dan radikal. Penafsiran dua ayat tidak ideologis atau historis, karena yang dilakukan oleh Quṭ hanya menjelaskan konsep hăkimiyyah asliyyah, dan sesuai dengan makna dasar atau kontek yang melatarbelakangi ayat tersebut. Sedangkan penafsiran terhadap lima belas ayat lainnya bersifat ahistoris atau ideologis, karena penjelasan Quṭb terhadap konsep hăkimiyyah tidak sesuai dengan historisitas ayat atau makna dasarnya, juga terdapat kerancuan dalam menafsirkan hākimiyyah tashrìiyyah kepada siyāsiyyah. Dan dari penafsrian ayat-ayat ahistoris tersebut terdapat penafsiran dua belas ayat yang bersifat radikal, karena selain penafsirannya tidak sesuai dengan historisitas ayat, katakata yang digunakan mengindikasikan kepada takfir.

Adapun kesimpulan kedua, terlihat bahwa penafsiran Quṭb yang ahistoris atau ideologis, tidak hanya dari ayat-ayat akidah atau yang berlandasan ibadah, tapi juga dari ayat-ayat yang menjelaskan hukum-hukum Islam. Hal ini membuktikan kebenaran penelitian 'Abdu al-Fattāh al-Khālidi, bahwa Quṭb dalam menafsirkan tafsir Fì Zilāl al-Qur'ān, memang memiliki orientasi untuk membuktikan kesatuan antara aspek akidah dan syariah. ${ }^{75}$ Namun, yang menjadikan penafsirannya ideologis adalah caranya memasukkan konsep hăkimiyyah serta seberapa besar proporsi yang digunakan. Hal ini diperkeruh dengan kata-kata, detil, generalisasi, struktur kalimat dan lainnya, yang hal tersebut menunjukkan benih radikal di dalamnya.

Mendukung kesimpulan di atas, konsep hăkimiyyah ini berasal dari konsep tawhïd. Tawhīd ini, bagi Quṭb terbagi menjadi dua; ulühiyyah dan rubūbiyyah. Adapun ulūhiyyah adalah kekuasaan Allah dalam perkara-perkara yang bersifat ijbāri, seperti pergantian malam dan siang dan lain-lain. Sedangkan rubübiyyah, adalah kekuasaan Allah dalam perkara-perkara ikhtiyāriyyah. Oleh karenanya, dalam tawhīd ulühiyyah terdapat ayat-ayat beraspek akidah, dan dalam tawhìd ikhtiyāriyyah, terdapat ayat-ayat beraspek syar'iyyah. Dan konsep hạkkimiyyah adalah tujuan dari konsep tawhìd. Maka,

\footnotetext{
${ }^{75}$ Bandingkan dengan Șalạ̣̄ 'Abdu al-Fattāḥ, Fỉ Zilāl al-Qur'ān fí al-Mïzān, 56.
} 
tidak heran jika dalam ayat-ayat akidah maupun syar'iyyah, Quṭb menjelaskan konsep hăkimiyyah. ${ }^{76}$

Kesimpulan ketiga, dari penafsiran-penafsiran Quṭb di atas, terlihat keterpengaruhannya dengan pengalaman-pengalaman yang ia alami terutama dalam pengalaman politiknya. Hal ini terlihat ketika Quṭ mengartikan konsep kedaulatan Tuhan dengan makna pemerintahan. Keadaan ini dimulai sejak ia melihat gaya hidup Amerika, sehingga ia merubah cara pandangannya dari pandangan liberalis menjadi seorang Islamis. Hal ini diperkeruh dengan hubungan yang menjadi buruk antara Quṭ, IM dengan pemerintahan Nasser, sehingga berujung kepada pembantaian dan dipenjaranya anggota IM. Oleh karena itu, tidak heran jika Quṭ menggunakan leksikon, detil atau struktur penafsiran yang mengindikasikan kepada penafsriannya yang politis.

Kesimpulan di atas diperkuat dengan revisi yang ia lakukan terhadap konsep hākimiyyah. Hal ini karena tafsir Fì Zilāl al-Qur'ān sendiri mengalami tiga tahap penulisan. Pertama, penulisan awal saat karyanya itu ditulis dalam sebuah artikel di jurnal al-muslimūn. Hanya saja, sebelum ia menyelesaikan penafsirannya pada seluruh ayat, Quṭb kemudian dipenjara tahun 1954 atas tuduhan merencanakan pemberontakan terhadap pemerintahan saat itu. Namun, pihak penerbit saat itu meminta pemerintah untuk mengizinkan Quṭ meneruskan tulisannya di balik jeruji penjara, hingga akhirnya ia menyelesaikan tafsirnya tersebut tahun 1959. Cetakan inilah yang dinamakan cetakan kedua. Hanya saja, karena penulisannya tersebut dibawah pengawasan ketat pemerintahan, ia berkeinginan untuk merevisi penulisan tafsir tersebut agar lebih sesuai dengan apa yang ia rasakan. Oleh karena itu, pasca penulisan tahun 1959, ia membuat revisi dari cetakan kedua itu. Hanya saja, ia berhasil merevisi sampai surah ke-15 (al-Hijr). Adapun setelah itu, adalah penafsirannya yang sama dengan cetakan-cetakan sebelumnya yang ada di jurnal almuslimūn. ${ }^{77}$ Melihat uraian di atas, nampaknya sesuai dengan penelitian penulis yang menemukan, bahwa konsep kedaulatan Tuhan ini ditemukan tidak melebihi surah 15, yakni hanya sampai pada Q.S. Ibrāhim (14).

Kesimpulan keempat, konsep hākimiyyah ini berhubungan erat dengan konsep jāhiliyyah. Hal ini terbukti dengan dijadikannya masa jāhiliyyah

${ }^{76}$ Ṣalāh 'Abdu al-Fattāh, Fì Zilāl al-Qur'ān fí al-Mizān, 56-58 dan Thameem Ushama, "Extremism in the Discourse of Sayyid Qutb: Myth and Reality," Intelectual Discourse (2007), 167-168.

${ }^{77}$ Bandingkan dengan Șalāh 'Abdu al-Fattāh, Madkhal ilā Fì Zilāl al-Qur'ān alQur'ān (Oman: Dār al-'Amār, 2000), 43-44, dan John Calvert, Sayyid Quṭ and the Origin of Radicalism, 205. 
tersebut sebagai latar untuk melihat masa kini. Dengan itu pula, Quṭb menyebut muslim yang tidak menjalankan syariat Islam dengan musyrik, sama seperti masyarakat jāhiliyyah yang menyekutukan Allah dalam segi ibadah. Perbedaannya, Muslim masa kini menyekutukan Allah di luar sektor ibadah, terutama dalam pemerintahan. ${ }^{78}$ Selain itu, keterkaitan antara hākimiyyahjāhiliyyah beserta penafsiran politisnya membuktikan, bahwa kedua konsep ini adalah bukti kuat atas ideologisasi radikalisasi Qutb dalam tafsirnya. ${ }^{79}$ Kesimpulan keempat ini, berbeda dengan pendapat al-Khālidi, yang mengatakan bahwa konsep jāhiliyyah tersebut tidak mengindikasikan kepada pengkafiran muslim, karena yang dimaksud dengan masyarakat jahiliyah adalah suatu komunitas yang sesat, dan hal itu tidak selamanya mengindikasikan kepada keluarnya seorang muslim dari Islam. Alasan al-Khālidi, kata $j-h-l$ itu sendiri dalam al-Qur'ān kembali kepada tiga macam; pertama tidak mengetahui (dan ini adalah arti dasar) kedua, meyakini sesuatu yang salah, dan ketiga melakukan sesuatu tidak benar, namun keyakininannya menolak hal tersebut. ${ }^{80}$ Kendati demikian, apa yang ada dalam tafsir Fì Zilāl al-Qur'ān menunjukkan hal berbeda. Pasalnya, Quṭb dengan terang-terangan mengatakan bahwa masyarakat jăhiliyyah adalah musyrik, begitu juga jăhiliyyah modern. Hal tersebut didukung dengan leksikon, kata-kata yang kontras serta detil yang diberikan saat menjelaskan "komunitas jahiliyah" dan "komunitas Islami." Oleh karena itu, penulis menyimpulkan bahwa kedua konsep tersebut-konsep kedaulaan Tuhan dan manusia-telah direinterpretasikan oleh Quṭ dengan maknanya yang siyāsi., sehingga penafsirannya terhadap kedua konsep tersebut bersifat ideologis, ahistoris dan beberapa darinya bahkan radikal. ${ }^{81}$ Meskipun demikian, tidak semua penjelasan dari tafsirnya bersifat ahistoris dan radikal, hingga harus

${ }^{78}$ Di antaranya adalah penafsiran Quṭb terhadap Q.S. al-An'̄̄m (6): 62, Q.S. alAnfāl (8): 27 dan Q.S. Yūsuf (12): 55.

79 Bandingkan dengan Thameem Ushama, "Extremism in the Discourse of Sayyid Qutb: Myth and Reality," Intelectual Discourse (2007): 167-168, AB. Rahman, Nooraihan Ali dan Wan Ibrahim, "The Influence of al-Aqqāed and Dīwān School of Poetry on Sayyid Qutb's Writings" International Journal of Humanities and Social Science 8, vol. 1 (Juli 2008): 158, www.ijhssnet.com/journals/Vol. 1No. 8; July 2011/18.pdf (diakses pada 15 Januari 2014), dan Hishām Ja'far, "Manhaj al-Naẓar ilā Mafhūmayy alHākimiyyah wa al-Jāhiliyyah," onislam (10 Agustus 2010), http://www.onislam.net/arabic/madarik/concepts/90810-2010-08-09-071215.html (diakses pada 6 April 2014).

${ }^{80}$ Bandingkan dengan Șalāh 'Abdu al-Fattāh, Fì Zilāl al-Qur'ān fỉ al-Mīzān, 196.

81 Untuk lebih jelasnya, silahkan merujuk kepada tesis penulis "Ahistorisitas Penafsiran dan Radikalisme Islam: Kajian terhadap Konsep Kedaulatan Tuhan dan Kedaulatan Manusia dalam Tafsir Fi Zilāl al-Qur'ān.” 
dihindari secara keseluruhan, karena bagaimanapun karyanya yang satu ini masih memiliki kelebihan lainnya seperti pada kata-katanya yang mencerminkan nilai sastra penulisnya serta ungkapannya yang khas. Maka, penulis menyarankan ketika merujuk kepada penafsiran Quṭb yang terdapat di dalamnya konsep kedaulatan Tuhan dan kedaulatan manusia, hendaknya tidak menerimanya secara literal, karena kognisi sosial Quṭb banyak mewarnai penafsirannya mengenai konsep-konsep tersebut, sehingga penafsirannya terhadap kedua konsep tersebut bersifat politis. Oleh karena itu, pembaca hendaknya didampingi dengan pengetahuan yang cukup mengenai kondisi sosial-politik di masa Quṭb tersebut.

\section{Daftar Pustaka}

Abduh, Muhammad. Tafsīr al-Manār. Kairo: al-Hay’ah al-Mișriyyah, 1990. Abdul Mustaqim. Epistemologi Tafsir Kontemporer. Jogjakarta: LKiS, 2010. Abou el-Fadl, Khaled Muhammad. Atas Nama Tuhan: Dari Fikih Otoriter ke Fikih Otoritatif. Penerjemah R. Cecep Lukman Yasin. Jakarta: Serambi, 2004.

al-Alūsì, Rūh al-Ma 'ānìi. Kairo: Dār al-Hadith, 2005.

Calvert, John. Sayyid Qutb and the Origin of Radical Islamism. New York: Columbia University Press, 2010. http://www.amazon.ca/Sayyid-QutbOrigins-Radical-Islamism/dp/0231701047 (diakses pada 1 September 2013).

-------. "Sayyid Qutb and the Origin of Radical Islamism." The Middle East Quarterlyvol 18, no 2: (2011): 13,http:/www.meforum.org/2945/sayyidqutb-and-the-origins-of-radical-islamism (diakses pada 1 September 2013).

Van Dijk, Teun A. Ideology and Discourse . http://www.discourses.org (diakses pada 12 Desember 2013).

Faiz, Fakhruddin. Hermeneutika al-Qur'ān: Tema-Tema Kontroversial. Jogjakarta: Elsaq press, 2005.

Hanafí, Hassan. Ḧiwār al-Ajyāl. Kairo: Dār al-Qubā,1998.

Ibn Katsir, Tafsìr al-Qur'ān al-Azīm. Kairo: Dār al-'Āthār, 2009.

Ibn, 'Āshūr. al-Tahrīr wa al-Tanwïr. Tunisia: al-Dār al-Tūnisiyyah, 1984.

Ibn Manz̦ur. Lisān al- 'Arab. Mesir: dār al-Ma'ārif, t.th.

al-Khālidi, Șalāh ‘Abdu al-Fattāh. Fì Zilāl al-Qur'ān fỉ al-Mizān. Oman: Dār 'Ammār, 2000. 
, Madkhal ilā Zilāl al-Qur'ān. Oman: Dār 'Ammār, 2000.

Khatab, Sayed. The Political Thought of Sayyid Qutb: The Theory of Jāhiliyyah. New York: Routledge , 2006.

--------, The Power of Sovereignty: The Political and Ideological Philosophy of Sayyid Qutb.New York: Routledge, 2006.

Mubarak, Ahmad Zaki. Pendekatan Strukturalisme Linguistik dalam Tafsir alQur'ān Kontemporer “ala” M. Shahrūr. Jogjakarta: ELSAQ Press, 2007. al-Qaraḍ̄āìi, Y ūsuf. "Qaḍiyyah al-Ḥākimiyyah wa Āthāruhu min Jadal, dan alDawlah al-Madaniyyah Marji'iyyatuhā Islām...kayfa?” Mawqi' alQaradāwi, 12 Desember 2009, http://WwW.qaradawi.net/articles/862009-12-12-10-35-10/5029-2011-09-25-11-44-39.html,(diakses pada 25 April 2012).

al-Qurțubi. Al-Jāmi 'li Aḥkām al-Qur'ān. Kairo: Maktbah al-Imān, tth. Quṭ, Sayyid. Fì Zilāl al-Qur'ān. Kairo: Dār al-Shurūq, 2003.

-------. Ma'ālim fỉ al-Ṭariq.Kairo: Dār al-Shurūq, 1979.

Al-Islām wa Mushkilät al-Hađ̣ārah. Kairo: Dār al-Shurūq, 1992.

Rahman, AB, Nooraihan Ali dan Wan Ibrahim. "The Influence of al-Aqqād and Dî̄Wān School of Poetry on Sayyid Quṭb's Writings" International Journal of Humanities and Social Science 8, vol. 1 (Juli 2008): 158, www.ijhssnet.com/journals/Vol._1No._8; July_2011/18.pdf (diaksespada 15 Januari 2014).

Rahman, Fazlur. "Pendekatan Terhadap Islam dalam Studi Agama." dalam Pendekatan Kajian Islam dalam Studi Islam, ed. Richard C. Martin. Penerjemah Zakiyuddin Baidhawi. Surakarta: Muhammadiyah University Press, 2002.

Saenong, Ilham B. Hermeneutika Pembebasan. Jakarta: Teraju, 2002.

al-Ṭabarì. Jämi' al-Bayān fì Ta’wìl 'Ayi al-Qur'ān. Kairo: Al-Maktabah alTawfíqiyyah, 2003.

Ushama, Thameem. "Extremism in the Discourse of Sayyid Qutb: Myth and Reality." Intelectual Discourse (2007): 167-168, http://www.iium.edu.my/intdiscourse/index.php/islam/article/view/49 (diakses pada 18 Januari 2014). 